\title{
Development the Six-Jaw Self-Centering Geared Scroll Chuck
}

\author{
A. S. Serkov ${ }^{1, *}$, V. B. Masyagin ${ }^{1}$, L. B. Serkova ${ }^{1}$, and R. I. Bazhenov ${ }^{2}$ \\ ${ }^{1}$ Omsk State Technical University, Mira 11, Omsk, 644050, Russia \\ ${ }^{2}$ Sholom-Aleikhem Priamursky State University, Shirokaya 70a, Birobidzhan, 679015, Russia
}

\begin{abstract}
In the article the development of device to reduce the form errors in workholding flexible thin-walled parts such as gears has been considered. The design and operation of the developed six-jaw selfcentering geared scroll chuck are described in detail, the well-known designs of self-centering 3-jaw and 6-jaw chucks are also considered, and their shortcomings are given.
\end{abstract}

\section{Introduction}

In the production of flexible thin-walled gears, in the process of their manufacture, there are problems associated with ensuring the accuracy of the shape and size of the base hole, the gear involute profile and their relative location relative to each other. When quenching or carburizing of the gear blank warping of its surfaces occurs, the axis of the center opening and the reference diameter relative to each other are shifted, the eccentricity error appears. In order to get rid of this error in the technological process after heat treatment, finishing operations are introduced (turning, grinding of working and base surfaces). If these operations are not introduced, then during operation such parts are more susceptible to increased wear, as a result of which the service life of the product will be reduced. In this case, there are errors of surface shapes due to the chucking force. There is a problem of reducing errors when workholding parts. This problem can be solved by developing an appropriate device.

\section{Problem statement}

In [1], the methodology of use of universal 3-jaw self-centered chuck is considered to workholding and subsequent processing (central openings grinding) of the gear blanks.

In [2-6], the results of the gear 3D model study by the finite element method (FEM) for the stress-strain state (SSS) were considered. The model is in static equilibrium under the action of the chucking force by the jaws of the self-centering chuck with different basing schemes.

According to the results of [2-6], the following conclusion was made: redistribution of chucking force to a larger number of its appendices to reduced as the elastic stresses

\footnotetext{
*Corresponding author: a Sanya_93@bk.ru
} 
magnitude, and, consequently, the deformations, and creates a uniform SSS of one sign on the form of hole, which minimizes it Impact on the distortion of the form after removing the force.

\section{Detailed Description}

According to the results of the work performed [1-6], a useful model was developed - sixjaw self-centering geared scroll chuck (Figure 1) [7].

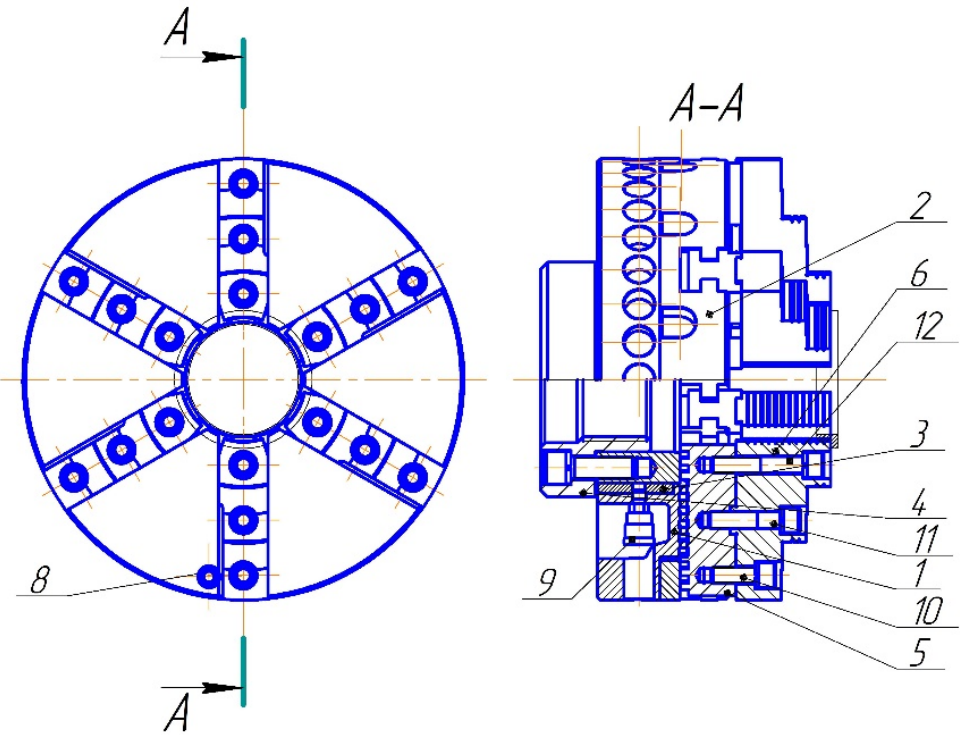

Fig. 1. Six-jaw self-centering geared scroll chuck.

Useful model refers to machine-tool construction and can be used to workholding blanks (axisymmetric body, shafts, sleeves, pipes, thin-walled blanks, pinion gears, gears, rings, etc.).

From the available prior art, a 6-jaw self-centering chuck is known [8], which has a chuck body, jaws insert, rails located in the grooves of the chuck body, as well as bevel gearing and scroll gear which are necessary to move the jaws insert.

The disadvantage of the structure [8] is the complexity of the bevel gearing manufacturing, as well as such a gear has the backlash, which in turn adversely affects to the blanks processing accuracy.

Also known is a self-centering chuck [9], which contains in its design a chuck body, jaws insert, six racks, lever arms, pillar, trunnions, driving arm, paired jaws.

The disadvantage of this design [9] is a large number of complex parts, as well as for blanks clamping - unclamping, a power pneumatic or hydraulic drive is required. The use of such a chuck will be irrational under the conditions of applying repair, individual, single piece, low-size, medium-size productions.

The closest in design to the declared engineering solution is the jaw self-centering geared scroll chuck [10], which has a scroll gear, the chuck body, three solid jaws, limit stop and a two-way key for clamping - unclamping blanks.

The disadvantage of such design is the insufficient presence of solid jaws because of this, the distribution of the chucking force occurs in three contact points of solid jaws with the blank, as a result of which there are quite large blank deformations (which is described 
in detail in [2-6]), consequently, due to which the accuracy of the blanks processing is reduced, also one of the disadvantages of the design [10] is the increased wear of sliding surface of the scroll gear central hole against the chuck body, which in turn reduces the blanks processing accuracy.

The technical result of the useful model [7] is aimed at the accuracy increase of blanks processing.

The chucking force distribution of the blanks occurs at six points of the jaws insert, thereby reducing the blanks deformation being clamped, therefore, this leads to an increase in the processing of blanks accuracy. The intermediate sleeve is made of a wear-resistant material, which significantly reduces the wear of the sliding surface, and during operation contributes to the preservation of the accuracy characteristics of the six-jaw self-centering geared scroll chuck for a long time, and in the case of repairing a six-jaw self-centering geared scroll chuck, the intermediate sleeve is press out and replaced by a new one.

In 'Figure 2' shows 2 projections of a two-way bidentate key 7, which is necessary for the blanks clamping - unclamping in a six-jaw self-centering geared scroll chuck.

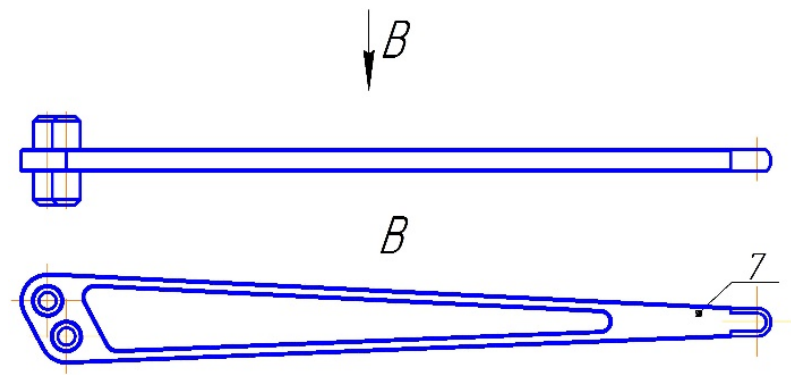

Fig. 2. Two-way bidentate key.

The six-jaw self-centering geared scroll chuck (Figure 1) consists of a chuck body 2, in which a scroll gear 1 with an intermediate sleeve 3 of a cylindrical shape made of wearresistant material is installed, the intermediate sleeve 3 is pressed-fit into the scroll gear central hole 1 coaxially with it and the chuck body 2 , the scroll gear outside surface 1 is made exactly butt to the chuck body 2 and has radial holes, the chuck body 2 at the place of the joint with the outside surface of scroll gear 1 is provided with grooves located along the generatrix. The grooves and holes perform the function of simultaneous capture by them with a two-way bidentate key 7 . The racks 5 are located in the guiding grooves of the chuck body 2 , and the jaws insert 6 are fixed with screws $10,11,12$ to the racks 5 . Scroll gear 1 with an intermediate sleeve 3 , installed on chuck body 2 using a faceplate 4 . Near one of the chuck body 2 grooves there is a limiting screw 8 , which is necessary to prevent the racks 5 with jaws insert 6 from flying out or falling out of the chuck body 2 guiding grooves during their free state. Oiler 9 is located on a scroll gear 1.

The device operates as follows.

With a faceplate 4 , the scroll gear 1 with the intermediate sleeve 3 is fixed on the chuck body 2 and the entire structure of the six-jaw self-centering geared scroll chuck is fixed on the main spindle.

To rotate the scroll gear 1 , with the intermediate sleeve 3 pressed-fit into it coaxially, and the movement of the racks 5 , with jaws insert 6 , fixed on them using screws $10,11,12$, on the chuck body 2 guiding grooves, one of the teeth of the two-way bidentate key 7 is inserted into the radial hole on the scroll gear 1 diametral surface, and the other tooth is inserted into the groove of the chuck body 2 (Figure 3), after which, when turning the twoway bidentate key 7 , a scroll gear 1 is rotated with an intermediate sleeve 3 relative to the 
chuck body 2, and rack 5 with the jaws insert 6 begin to move perpendicular to the axis of rotation of the main spindle, as a result of which the blank is clamped.

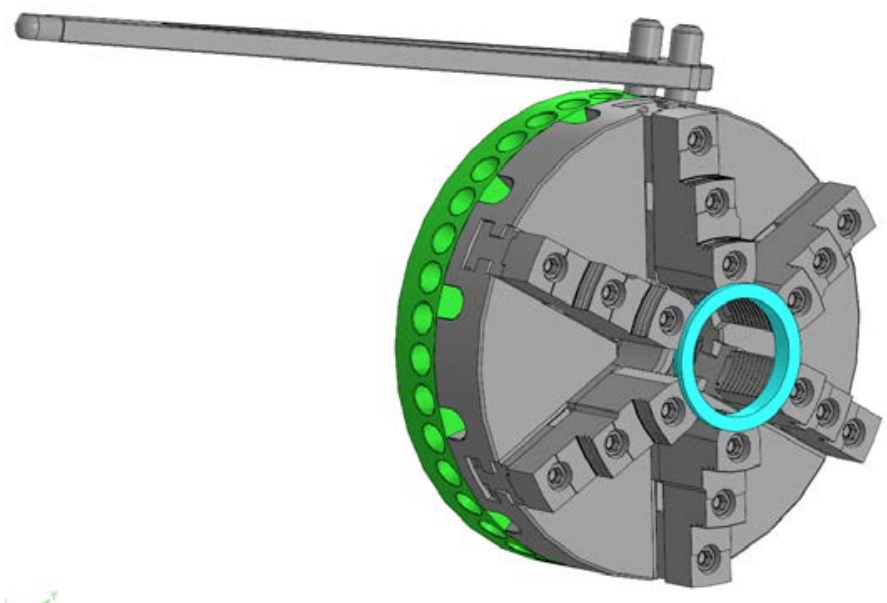

Fig. 3. The six-jaw self-centering geared scroll chuck flow chart.

If it is necessary to quickly move the jaws insert 6 to a new clamping diameter, it is possible to directly rotate the scroll gear 1 using the rounded part of the handle of the twoway bidentate key 7 . The working surfaces of the intermediate sleeve 3 and the chuck body 2 are lubricated with an oiler 9 by pouring industrial oil into the threaded hole in intermediate sleeve 3. The limiting screw 8 prevents the racks 5 with jaws insert 6 from falling out of the guiding grooves of the chuck body 2 .

The number of radial holes on the outside surface diameter of the scroll gear 1 is selected in such a way that at any position of the scroll gear 1 relative to the chuck body 2 in the immediate vicinity of each groove of the chuck body 2 , one of the holes of the scroll gear 1 , which allows you to hook at the same time two-way bidentate key 7 scroll gear 1 and chuck body 2 .

\section{Conclusions}

Such a constructive solution is simple in operation, maintenance, and processible, and also makes it possible to produce flexible thin-walled parts with high precision.

The reported study was funded by RFBR, project number 20-38-90226.

\section{References}

1. Serkov A S, Sayfulin I I, Palina O V 2017 Snizhe-sebestoimost' shlifovaniya posadochnykh otverstiy i tortsov tsilin-dricheskikh pryamykh zubchatykh koles za schot vnedreniya universal'noy osnastki Innovatsii, kachestvo i servis $v$ tekhnike $i$ tekhnologiyakh: sb. tr. konf. Kursk: Universitetskaya kniga pp 323-328. ISBN 978-59908594-1-8

2. Rogov V A, Koshelenko A S, Khishova Ye S 2015 Issledovaniye naprya-zhonnogo sostoyaniya zubchatogo ventsa na opticheskikh modelyakh ot sil zazhima v samotsentriruyushchem patrone Vestnik Rossiyskogo Universiteta Druzhby Narodov. Seriya: inzhenernyye issledovaniya. M .: Izd-vo RUDN,. № 4 pp 29-37 
3. Rogov V A, Koshelenko A S, Khishova Ye S 2015 Issledovaniye metodom fotomekhaniki napryazhenno-deformirovannogo sostoyaniya zubchatogo ventsa, vyzvannogo zazhimom $\mathrm{v}$ samotsentriruyushchem patrone pri mekhanicheskoy obrabotke Vestnik MGTU «Stankin» № 4 (35) pp 36-41

4. Rogov V A, Koshelenko A S, Zhed' O V, Khishova Ye S 2016 Issledo-vaniye metodom fotomekhaniki napryazhenno-deformirovannogo so stoyaniya zubchatogo ventsa ot zazhima $\mathrm{v}$ samotsentriruyushchem patrone na etapakh mekhanicheskoy obrabotki Gruzovik № 2 pp 19-22

5. Rogov V A, Koshelenko A S, Khishova Ye S 2016 Issledovaniye naprya-zhennogo sostoyaniya zubchatogo ventsa na opticheskikh modelyakh ot silovykh zazhimov v samotsentriruyushchem patrone Tekhnologiya mashinostroyeniya. № 3 pp 10-14

6. Serkov A S, Masyagin V B, Artyukh R L, Serkova L B, Akimov V V 2020 Issledovaniye napryazhonno-deformirovannogo sostoyaniya zagotovki zubchatogo kolesa $\mathrm{s}$ primeneniyem matematicheskikh modeley $\mathrm{v}$ zavisimosti ot silovykh zazhimov v 3-kh i 6-ti kulachkovykh samotsentriruyushchikh patronakh Omskiy nauchnyy vestnik. № 4 (172) pp 13-18

7. Shestikulachkovyy samotsentriruyushchiy spiral'no-reyechnyy patron: pat. RU201747U1 Ros. Federatsiya: IPC B23B 31/16

8. Shestikulachkovyy samotsentriruyushchiy patron: pat. SU908545 SSSR: IPC B23B 31/169, IPC B23B 31/16, A1

9. Samotsentriruyushchiy patron: pat. SU656745A1 SSSR: IPC B23B31/ 12

10. Samotsentriruyushchiy kulachkovyy spiral'no-reyechnyy patron: pat. SU94330 SSSR: IPC B23Q 1/25, IPC B23B 31/10 A1 